Boise State University

ScholarWorks

Early and Special Education Faculty

Publications and Presentations

Department of Early and Special Education

7-7-2021

A Systematic Review of the Quality of Reporting in Mathematics

Meta-Analyses for Students with or at Risk of Disabilities Coding

Protocol

Gena Nelson

Boise State University 


\title{
A Systematic Review of the Quality of Reporting in Mathematics Meta-Analyses for Students with or At Risk of Disabilities
}

\begin{abstract}
The purpose of this document is to provide readers with the coding protocol that authors used to code 22 meta-analyses focused on mathematics interventions for students with or at-risk of disabilities. The purpose of the systematic review was to evaluate reporting quality in meta-analyses focused on mathematics interventions for students with or at risk of disabilities. To identify meta-analyses for inclusion, we considered peer-reviewed literature published between 2000 and 2020; we searched five education-focused electronic databases, scanned the table of contents of six special education journals, reviewed the curriculum vitae of researchers who frequently publish meta-analyses in mathematics and special education, and scanned the reference lists of meta-analyses that met inclusion criteria. To be included in this systematic review, meta-analyses must have reported on the effectiveness of mathematics-focused interventions, provided a summary effect for a mathematics outcome variable, and included school-aged participants with or at risk of having a disability. We identified 22 metaanalyses for inclusion. We coded each meta-analysis for 53 quality indicators (QIs) across eight categories based on recommendations from Talbott et al. (2018). Overall, the meta-analyses met $61 \%$ of QIs and results indicated that meta-analyses most frequently met QIs related to providing a clear purpose (95\%) and data analysis plan (77\%), whereas meta-analyses typically met fewer QIs related to describing participants (39\%) and explaining the abstract screening process (48\%). We discuss the variation in QI scores within and across the quality categories and provide recommendations for future researchers so that reporting in meta-analyses may be enhanced. Limitations of the current study are that grey literature was not considered for inclusion and that only meta-analyses were included; this limits the generalizability of the results to other research syntheses (e.g., narrative reviews, systematic reviews) and publication types (e.g., dissertations).
\end{abstract}

Keywords: meta-analysis, mathematics, intervention, disability

The dataset that accompanies this coding protocol can be found here: https//doi.org/10.18122/sped_data.1.boisestate 
Publication Codes

\begin{tabular}{|l|l|l|l|}
\hline Cell & Variable & Code & Explanation \\
\hline A & Authors & Name & List all authors' last names \\
\hline B & Year & Number & Record year of publication \\
\hline C & Journal & Name & Record journal; Use full name, do not use acronyms \\
\hline
\end{tabular}

NOTE: For Quality Indicator codes; $0=$ the quality indicator was not addressed at all in the meta-analysis; $1=$ the quality indicator was somehow addressed in the manuscript.

\begin{tabular}{|c|c|c|c|}
\hline Cell & Variable & Code & Explanation \\
\hline D-I & $\begin{array}{l}\text { Clear Research } \\
\text { Questions and } \\
\text { Conceptualization for } \\
\text { the Study }\end{array}$ & $\begin{array}{l}\text { Mark } 0,1 \text { for all variables: } \\
\text { - } \text { previous research } \\
\text { summarized }(\mathrm{D}) \\
\text { - } \text { contribution to the field } \\
\text { (E) } \\
\text { - define key variables }(\mathrm{F}) \\
\text { - clearly stated purpose }(\mathrm{G}) \\
\text { - } \text { indicating the types of } \\
\text { participants }(\mathrm{H}) \\
\text { - } \text { provide clearly stated } \\
\text { research question }(\mathrm{J})\end{array}$ & $\begin{array}{l}\text { Codes defined: } \\
D=\text { previous research summarized: previous research is } \\
\text { summarized providing a rationale for the current study. } \\
D=\text { contribution to the field is specifically noted, such as the } \\
\text { unique contribution or how the results will impact researchers or } \\
\text { practitioners, or perhaps how the current study addresses the } \\
\text { limitations of previous reviews. } \\
F=\text { define key variables: key variables aligned with the study are } \\
\text { defined (e.g., math difficulty, intervention, learning disability). } \\
\text { This is a bit arbitrary depending on what the authors chose to } \\
\text { define. Mark } 1 \text { if authors operationally defined at least } 1 \\
\text { important construct related to either: disability or risk, or the } \\
\text { definition of an intervention. } \\
G=\text { clearly stated purpose for the review such as formulating } \\
\text { new theory, examining the evidence base of an instructional } \\
\text { practice or intervention program } \\
H=\text { indicating the types of participants who are of interest in the } \\
\text { studies and providing information about participants in the } \\
\text { introduction (e.g., what is MLD). } \\
\mathrm{J}=\text { provide clearly stated research question. }\end{array}$ \\
\hline
\end{tabular}




\begin{tabular}{|c|c|c|c|}
\hline Cell & Variable & Code & Explanation \\
\hline $\mathrm{J}$ & $\begin{array}{l}\text { Range of } \\
\text { Publication }\end{array}$ & $\begin{array}{l}\text { Select one: } \\
0=\text { no } \\
1=\text { yes }\end{array}$ & $\begin{array}{l}\text { Codes Defined: } \\
\text { - there was not a range of publication years provided in } \\
\text { the search or inclusion criteria. } \\
\text { - There was a range of publication years provided in the } \\
\text { search or inclusion criteria. }\end{array}$ \\
\hline K & $\begin{array}{l}\text { Type of Literature } \\
\text { Considered }\end{array}$ & $\begin{array}{l}\text { Select one: } \\
0=\text { authors did not specify } \\
1=\text { peer-reviewed articles only } \\
2=\text { peer-reviewed and grey } \\
\text { literature }\end{array}$ & $\begin{array}{l}\text { Codes defined: } \\
0=\text { authors did not specify if they searched peer-reviewed or } \\
\text { grey literature } \\
1=\text { peer-reviewed articles only (also peer-refereed) } \\
2=\text { peer-reviewed and grey literature (including dissertations, } \\
\text { book chapters, conference proposals, technical reports, etc.) }\end{array}$ \\
\hline $\mathrm{L}$ & $\begin{array}{l}\text { Language } \\
\text { Requirements }\end{array}$ & $\begin{array}{l}\text { List Language of Publication } \\
\text { Requirement }\end{array}$ & $\begin{array}{l}\text { List the languages of publication that were considered, list NA } \\
\text { if not mentioned. }\end{array}$ \\
\hline $\mathrm{M}$ & $\begin{array}{l}\text { Math Content } \\
\text { Focus (Ind. } \\
\text { Variable) is } \\
\text { Identified in } \\
\text { Inclusion/Exclusio } \\
\text { n Criteria }\end{array}$ & $\begin{array}{l}\text { Select one: } \\
0=\mathrm{NA} \text {; the Ind. Variable is } \\
\text { not a math content area } \\
1=\text { Yes there is a math content } \\
\text { area that is the ind. variable } \\
\text { BUT it is NOT specified in the } \\
\text { inclusion/exclusion. } \\
2=\text { yes, the independent } \\
\text { variable was listed or } \\
\text { identified as a math content } \\
\text { area AND it is addressed in the } \\
\text { inclusion/exclusion criteria. }\end{array}$ & $\begin{array}{l}\text { This code refers to whether or not the author/study simply } \\
\text { identified or mentioned the skill or intervention focus that is the } \\
\text { independent variable. } \\
\text { - NA = the variable of interest is not a math content area, } \\
\text { but instead an instructional strategy (e.g., peer tutoring) } \\
\text { - } 1=\text { The article either did not specify the type of } \\
\text { intervention that is the focus of the meta-analysis, or the } \\
\text { meta-analysis was vague and it was not immediately } \\
\text { clear what the independent variable was. } \\
\text { - } 2=\text { yes, the article makes statements about the focus of } \\
\text { the meta-analysis and type of intervention that is the } \\
\text { independent variable. For example, the article might } \\
\text { state, "The intervention focused on ratio and unit rate } \\
\text { concepts." Or "The independent variable of the included } \\
\text { studies was a numeracy intervention." }\end{array}$ \\
\hline
\end{tabular}




\begin{tabular}{|c|c|c|c|}
\hline $\mathrm{N}$ & $\begin{array}{l}\text { Math Content } \\
\text { Focus (Ind. } \\
\text { Variable) is } \\
\text { Operationally } \\
\text { Defined (this could } \\
\text { be included in the } \\
\text { literature review, } \\
\text { purpose, and } \\
\text { Method) }\end{array}$ & $\begin{array}{l}\text { Select one: } \\
0=\text { NA; The Ind. Variable of } \\
\text { interest in the meta-analysis is } \\
\text { not a content focus; but an } \\
\text { instructional strategy } \\
1=\text { No, not reported (the } \\
\text { author/article did not provide } \\
\text { how their intervention defined } \\
\text { the ind. variable) } \\
2=\text { yes, the author/article } \\
\text { provided how their } \\
\text { intervention defined the ind. } \\
\text { variable }\end{array}$ & $\begin{array}{l}\text { This refers to whether or not the author or article provide how } \\
\text { the research team envisioned the concept or skill (ind. Variable) } \\
\text { in relation to their own intervention. The article does not have } \\
\text { to read, "we define ratio as..." but there does need to be text } \\
\text { provided for the reader to understand how the research team } \\
\text { defined the concept. For a good example of how "broad } \\
\text { mathematics intervention" focus is defined, see Stevens et al. } \\
\text { (2019). } \\
\text { Use NA when the variable of interest is a strategy instead of a } \\
\text { content focus (e.g., schema-based instruction). }\end{array}$ \\
\hline $\mathrm{O}$ & $\begin{array}{l}\text { If Ind. Variable is } \\
\text { an Instructional } \\
\text { Strategy (e.g., SBI, } \\
\text { peer tutoring) it is } \\
\text { Identified in } \\
\text { Inclusion/Exclusio } \\
\text { n Criteria }\end{array}$ & $\begin{array}{l}\text { Select one: } \\
0=\text { NA; The Ind. Variable of } \\
\text { interest in the meta-analysis is } \\
\text { not an instructional variable } \\
\text { focus; but a content focus } \\
1=\text { No, the ind. Variable is an } \\
\text { instructional feature but it is } \\
\text { not identified in the } \\
\text { inclusion/exclusion criteria } \\
2=\text { yes, the author/article } \\
\text { provided how their } \\
\text { instructional features is } \\
\text { identified in the } \\
\text { inclusion/exclusion criteria }\end{array}$ & $\begin{array}{l}\text { Similar to the math content focus variables above. If the authors } \\
\text { specify that the main focus is on math interventions that use } \\
\text { schema-based instruction, peer tutoring, cognitive strategy } \\
\text { instruction, etc. the ind. Variable of interest is likely the } \\
\text { instructional feature. It could also be a content area (e.g., peer } \\
\text { tutoring within word problem solving interventions). }\end{array}$ \\
\hline $\mathrm{P}$ & $\begin{array}{l}\text { If Ind. Variable is } \\
\text { an Instructional } \\
\text { Strategy (e.g., SBI, } \\
\text { peer tutoring) it is } \\
\text { Operationally } \\
\text { Defined }\end{array}$ & $\begin{array}{l}\text { Select one: } \\
0=\text { NA; no instructional } \\
\text { feature as a variable } \\
1=\text { No, the ind. Variable is an } \\
\text { instructional feature but it is } \\
\text { operationally defined }\end{array}$ & $\begin{array}{l}\text { Similar to the math content focus variables above. If the authors } \\
\text { specify that the main focus is on math interventions that use } \\
\text { schema-based instruction, peer tutoring, cognitive strategy } \\
\text { instruction, etc. the ind. Variable of interest is likely the } \\
\text { instructional feature. It could also be a content area (e.g., peer } \\
\text { tutoring within word problem solving interventions). }\end{array}$ \\
\hline
\end{tabular}




\begin{tabular}{|c|c|c|c|}
\hline & $\begin{array}{l}\text { this could be } \\
\text { included in the } \\
\text { literature review, } \\
\text { purpose, and } \\
\text { Method) }\end{array}$ & $\begin{array}{l}2=\text { yes, the author/article } \\
\text { provided how their } \\
\text { instructional features is } \\
\text { operationally defined }\end{array}$ & \\
\hline Q & $\begin{array}{l}\text { Math Outcome } \\
\text { Measure (Dep } \\
\text { Variable) }\end{array}$ & $\begin{array}{l}\text { Selected one: } \\
0=\text { No math academic } \\
\text { outcome measure requirements } \\
1=\text { Study listed math academic } \\
\text { outcome measure requirements }\end{array}$ & $\begin{array}{l}\text { Codes defined as: } \\
\bullet \quad 0=\text { Study did not specify any outcome measure } \\
\text { requirements for inclusion or exclusion specifically } \\
\text { related to math academic outcomes (e.g., CBM, } \\
\text { computation fluency, achievement, WPS) } \\
\text { - } 1 \text { = Study specified outcome measure requirements for } \\
\text { inclusion or exclusion that were related to math } \\
\text { academic outcomes (e.g., "study must include } \\
\text { dependent measure of fraction computation") }\end{array}$ \\
\hline $\mathrm{R}$ & Grade/Age Code & $\begin{array}{l}\text { Selected one: } \\
0=\text { No grade/age requirements } \\
1=\text { Study listed grade/age } \\
\text { requirements }\end{array}$ & $\begin{array}{l}\text { Codes defined as: } \\
\bullet \quad 0=\text { Study did not specify any grade/age } \\
-1=\text { Study specified grade/age requirements for inclusion } \\
\text { or exclusion (e.g., } 6-12^{\text {th }} \text { grade, kindergarten }-6^{\text {th }} \text { grade) }\end{array}$ \\
\hline
\end{tabular}




\begin{tabular}{|c|c|c|c|}
\hline $\mathrm{S}$ & $\begin{array}{l}\text { Participant } \\
\text { Disability or Risk } \\
\text { Requirements Code }\end{array}$ & $\begin{array}{l}\text { Selected one: } \\
0=\text { Participant Disability or } \\
\text { Risk requirement was not } \\
\text { specified in the Inclusion } \\
\text { Criteria } \\
1=\text { Disability only required } \\
2=\text { Risk or low achievement } \\
\text { only required } \\
3=\text { Mix of disability and risk } \\
4=\text { Mix of disability, risk, or a } \\
\text { threshold of disability/risk with } \\
\text { typically achieving (this does } \\
\text { not refer to mixing different } \\
\text { types of disability such as } \\
\text { ADHD and LD, it refers to } \\
\text { mixing disability OR risk } \\
\text { WITH typically achieving or a } \\
\text { threshold). }\end{array}$ & $\begin{array}{l}\text { Codes defined as: } \\
\text { - } 0 \text { = The inclusion criteria for the meta-analysis did not } \\
\text { address disability or risk, but the authors did provide } \\
\text { disaggregated results for one of these risk populations. } \\
\text { - } 1 \text { = Study specified that only studies with students with } \\
\text { disabilities (or a specific type of disability) were } \\
\text { included } \\
\text { - } 2 \text { = Study specified that only studies with students who } \\
\text { were at-risk of disabilities (e.g., reading difficulty) were } \\
\text { included } \\
\text { - } 3=\text { Study specified that studies with students with } \\
\text { disabilities or who were at-risk of disabilities (e.g., } \\
\text { reading difficulty) were included (Note: this may } \\
\text { include other categories such as low achieving, } \\
\text { struggling learning, or behavior challenge) } \\
\text { 4= Study specified that either students with disabilities } \\
\text { or at-risk for disabilities were included, as well as } \\
\text { typically achieving students }\end{array}$ \\
\hline $\mathrm{T}$ & $\begin{array}{l}\text { Participant } \\
\text { Disability Criteria }\end{array}$ & $\begin{array}{l}\text { Note all that apply related to } \\
\text { disability requirement: } \\
0=\text { Not Applicable } \\
1=\text { percentile cutoff } \\
2=\text { school, district, or state } \\
\text { criteria } \\
3=\text { documented } \\
4=\text { IEP goal } \\
5=\text { Services in special } \\
\text { education setting } \\
6=\text { Other } \\
7=\text { Not described }\end{array}$ & $\begin{array}{l}\text { Codes defined as: } \\
\text { - Not applicable = The authors did not include } \\
\text { participants with disabilities in their meta-analysis, or } \\
\text { the authors did not include disability as inclusion criteria } \\
\text { and therefore, it was not addressed. } \\
\text { - Percentile = authors used a percentile to state students } \\
\text { had LD, such as performing below the } 10^{\text {th }} \text { percentile on } \\
\text { a measure of math achievement. } \\
\text { - School, district, or state criteria = Authors stated that } \\
\text { participants had LD according to criteria } \\
\text { Documented = Authors stated that the participants had a } \\
\text { documented disability (e.g., authors confirmed ASD } \\
\text { through documentation; generally, not coded with any } \\
\text { other category). }\end{array}$ \\
\hline
\end{tabular}




\begin{tabular}{|c|c|c|c|}
\hline & & $\begin{array}{l}\text { Separate responses using a } \\
\text { semi-colon (e.g., " } 1 ; 3 ; 4 \text { ") }\end{array}$ & $\begin{array}{l}\text { IEP = Authors stated that the participants that had IEPs } \\
\text { goals } \\
\text { - Special education setting = Authors stated that students } \\
\text { who received special education services or related } \\
\text { services in a specific setting (e.g., self-contained, co- } \\
\text { taught or inclusive settings, residential school) } \\
\text { - Other = Authors used other criteria and specified what } \\
\text { criteria were } \\
\text { Not described = Authors stated that students with } \\
\text { disabilities were a focus of their study, but the authors } \\
\text { did not provide difficulty criteria they used (authors of } \\
\text { the meta-analysis may also state that students were } \\
\text { identified with MLD, MD, etc. with methods 'as } \\
\text { described by the author' although, the specific criteria } \\
\text { are still not described). }\end{array}$ \\
\hline$\overline{\mathrm{U}}$ & $\begin{array}{l}\text { Participant } \\
\text { Difficulty or Risk } \\
\text { Criteria (note: This } \\
\text { may also be } \\
\text { referred to as } \\
\text { "struggling learner" } \\
\text { "behavior } \\
\text { challenges" or } \\
\text { "poor academic } \\
\text { skills") }\end{array}$ & $\begin{array}{l}\text { Note all that apply: } \\
0=\text { Not applicable } \\
1=\text { percentile cut off on a } \\
\text { screening test or measure } \\
2=\text { teacher or parent referral or } \\
\text { identification } \\
3=\text { state test scores/benchmark } \\
4=\text { Receiving Intervention for } \\
\text { outcomes related to } \\
\text { risk/difficulty } \\
5=\text { Other } \\
6=\text { Not Described } \\
\text { Separate responses using a } \\
\text { semi-colon (e.g., "1; } 3 ; 4 ")\end{array}$ & $\begin{array}{l}\text { Codes defined as: } \\
\text { - Not applicable }=\text { The authors did not include } \\
\text { participants with disabilities in their meta-analysis, or } \\
\text { the authors did not include disability as inclusion criteria } \\
\text { and therefore, it was not addressed. } \\
\text { - Percentile = authors used a percentile to state students } \\
\text { had difficulty/risk, such as performing below the } 25^{\text {th }} \\
\text { percentile on a measure of reading achievement. } \\
\text { - Referral = parents or teachers referred students for } \\
\text { difficulty in an academic or social/behavior area } \\
\text { - State or district criteria = Authors stated that participants } \\
\text { had difficulty according to state or district criteria } \\
\text { - Receiving Intervention = Authors stated that students } \\
\text { were included as at-risk or difficulty due to receiving } \\
\text { targeted services } \\
\text { Other = Authors used other criteria and specified what } \\
\text { criteria were }\end{array}$ \\
\hline
\end{tabular}




\begin{tabular}{|c|c|c|c|}
\hline & & & $\begin{array}{l}\text { Not described = Authors stated that students with } \\
\text { difficulty or risk were a focus of their study, but the } \\
\text { authors did not provide difficulty criteria they used } \\
\text { (authors of the meta-analysis may also state that } \\
\text { students were identified with MLD, MD, etc. with } \\
\text { methods 'as described by the author' although, the } \\
\text { specific criteria are still not described). }\end{array}$ \\
\hline $\mathrm{V}$ & $\begin{array}{l}\text { Design } \\
\text { Requirements Code }\end{array}$ & $\begin{array}{l}\text { Selected one: } \\
0=\text { No design requirements } \\
\text { (must mark } 0 \text { for the next } \\
\text { code) } \\
1=\text { Study listed design } \\
\text { requirements }\end{array}$ & $\begin{array}{l}\text { Codes defined as: } \\
\bullet \quad 0=\text { Study did not specify any design requirements for } \\
\text { inclusion or exclusion } \\
\text { - } 1 \text { = Study specified design requirements for inclusion or } \\
\text { exclusion (e.g., group design, randomized control trial, } \\
\text { regression discontinuity, single case) }\end{array}$ \\
\hline
\end{tabular}

Quality of Search Procedures
\begin{tabular}{|l|l|l|l|}
\hline Cell & Variable & Code & Explanation \\
\hline W & $\begin{array}{l}\text { Stated Electronic } \\
\text { Databases that were } \\
\text { searched }\end{array}$ & $\begin{array}{l}\text { Select one: } \\
0=\text { no } \\
1=\text { yes }\end{array}$ & $\begin{array}{l}\text { Authors stated which electronic library data-bases were } \\
\text { searched. }\end{array}$ \\
\hline X & $\begin{array}{l}\text { Provided the Search } \\
\text { Terms }\end{array}$ & $\begin{array}{l}\text { Select one: } \\
0=\text { no } \\
1=\text { yes }\end{array}$ & $\begin{array}{l}\text { Authors specified which combination of search terms were } \\
\text { used for the electronic search. }\end{array}$ \\
\hline Y & $\begin{array}{l}\text { Search Methods } \\
\text { used }\end{array}$ & $\begin{array}{l}\text { Select all that apply: } \\
0=\text { Search not clearly detailed } \\
\text { enough to select at least one of } \\
\text { the options below. } \\
1=\text { reference lists of relevant } \\
\text { reviews } \\
2=\text { reference lists of included } \\
\text { studies } \\
3=\text { contact authors or experts in } \\
\text { the field }\end{array}$ & $\begin{array}{l}\text { Select as many that apply. Only select "0 if no information } \\
\text { about the search methods are provided. } \\
\text { Separate responses using a semi-colon (e.g., "1; 3; 4") }\end{array}$ \\
\hline
\end{tabular}




\begin{tabular}{|l|l|l|l|}
\hline & & $\begin{array}{l}4=\text { table of contents of relevant } \\
\text { journals (maybe referred to as } \\
\text { hand search) } \\
5=\text { forward citation search } \\
6=\text { other (List other methods) }\end{array}$ & \\
\hline Z & $\begin{array}{l}\text { Credentials of } \\
\text { Searchers }\end{array}$ & $\begin{array}{l}\text { Select one: } \\
0=\text { no } \\
1=\text { yes }\end{array}$ & $\begin{array}{l}\text { The credentials of the person(s) conducting the search were } \\
\text { specified. Note: If the article states something along the lines } \\
\text { of "the first author conducted the search" that is not the } \\
\text { equivalent of specifying the credentials. }\end{array}$ \\
\hline AA & $\begin{array}{l}\text { Number of } \\
\text { Searchers }\end{array}$ & $\begin{array}{l}\text { Select one } \\
0=\text { no } \\
1=\text { yes }\end{array}$ & \\
\hline
\end{tabular}

\begin{tabular}{|c|c|c|c|}
\hline Cell & Variable & Code & Explanation \\
\hline $\begin{array}{l}\mathrm{AB}- \\
\mathrm{AH}\end{array}$ & $\begin{array}{l}\text { Methods to } \\
\text { Screening studies } \\
\text { for inclusion and } \\
\text { exclusion from the } \\
\text { review. }\end{array}$ & $\begin{array}{l}\text { Mark } 0,1 \text { for all variables: } \\
\text { - number retrieved (AL) } \\
\text { - number screened out (AM) } \\
\text { - reasons for exclusion (AN) } \\
\text { - total eligible studies (AO) } \\
\text { - training for screening (AP) } \\
\text { - details for reliability of } \\
\text { screening process (AQ) } \\
\text { - reliability of screening } \\
\text { process (AR) }\end{array}$ & $\begin{array}{l}\text { Codes defined as: } \\
\text { AL = states the number of studies successfully retrieved } \\
\text { AM = states the number of studies screened out because they did } \\
\text { not meet eligibility criteria } \\
\text { AN = provides the reasons the excluded studies were excluded } \\
\text { AO = states the total number of studies eligible (included) in the } \\
\text { review } \\
\text { AP = describes the training and expertise of those who conducted } \\
\text { the screening process } \\
\text { AQ = provides details for the method used to resolve any } \\
\text { disagreements between screeners (e.g., discussed articles we did } \\
\text { not agree on to determine inclusion) } \\
\text { AR = reliability or interobserver agreement statistics used to } \\
\text { evaluate the consistency of the screening process (e.g., provides } \\
\text { the agreement \% for the screening process) }\end{array}$ \\
\hline
\end{tabular}


Quality of Coding Procedures

\begin{tabular}{|c|c|c|c|}
\hline Cell & Variable & Code & Explanation \\
\hline $\begin{array}{l}\mathrm{AI}- \\
\mathrm{AO}\end{array}$ & $\begin{array}{l}\text { Quality of the } \\
\text { Coding Scheme }\end{array}$ & $\begin{array}{l}\text { Mark } 0,1 \text { for all variables: } \\
\text { - } \quad \text { expertise (AS) } \\
\text { - } \text { training (AT) } \\
\text { - } \text { double-coded (AU) } \\
\text { for reliability statistics } \\
\text { - } \text { how/if disagreements } \\
\text { - } \text { were resolved (AW) } \\
\text { description of the } \\
\text { - } \\
\text { whading scheme (AX) } \\
\text { scheme looked like } \\
\text { (AY) }\end{array}$ & $\begin{array}{l}\text { Codes Defined } \\
\text { AS = the expertise of researchers who coded studies; Note: If the } \\
\text { article states something along the lines of "the first author } \\
\text { conducted all coding" that is not the equivalent of specifying the } \\
\text { credentials. } \\
\text { AT = the training procedures for using the coding scheme } \\
\text { AU = the number } \% \text { and percent of studies that were double- } \\
\text { coded for reliability } \\
\text { AV = the reliability statistics used to evaluate the consistency of } \\
\text { each domain/category of the coding scheme } \\
\text { AW = the procedures used to resolve disagreements; often, this } \\
\text { will just be a statement saying that disagreements were resolved } \\
\text { via discussion between coders. } \\
\text { AX = the authors provided a brief review of the variables they } \\
\text { coded for (e.g., such as categories or titles of codes) } \\
\text { AY = the response categories available for coders to select from } \\
\text { (providing a coding sheet might be an example); specific } \\
\text { information about how variables of interest were coded such as } \\
\text { by providing examples in text (Stevens et al., } 2018 \text { is a good } \\
\text { example of in text description to this level) }\end{array}$ \\
\hline
\end{tabular}

Quality of Reporting Study Quality

\begin{tabular}{|c|c|c|c|}
\hline Cell & Variable & Code & Explanation \\
\hline $\begin{array}{l}\mathrm{AP} \\
\mathrm{AQ}\end{array}$ & $\begin{array}{l}\text { Study Quality (Did } \\
\text { the meta-analysis } \\
\text { code the studies for } \\
\text { quality?) }\end{array}$ & $\begin{array}{l}\text { Select one: } \\
0=\text { nothing related to quality } \\
\text { was reported. } \\
1=\text { yes, quality was coded for } \\
\text { but there were not results } \\
\text { presented related to quality } \\
2=\text { yes, quality was coded for } \\
\text { and results were reported }\end{array}$ & $\begin{array}{l}\text { - } 0=\text { Nothing related to study quality was reported. } \\
\text { - } 1=\text { study quality was coded for the meta-analysis, but } \\
\text { results for quality were not presented. } \\
\text { - } 2=\text { yes, quality was coded for and results (such as an } \\
\text { average quality score or moderator analysis) were } \\
\text { reported. }\end{array}$ \\
\hline
\end{tabular}




\begin{tabular}{|l|l|l|}
\hline & & $\begin{array}{l}\text { Note: Quality might be referred to as quality indicators, CEC } \\
\text { guidelines, WWC guidelines, evidence-based practice review, } \\
\text { and methodological rigor. Methodological rigor means that } \\
\text { studies may have been excluded for high attrition, for example, } \\
\text { or not being able to appropriately gather results from the study. }\end{array}$ \\
\hline
\end{tabular}

\begin{tabular}{|c|c|c|c|}
\hline Cell & Variable & Code & Explanation \\
\hline AR & Total $N$ Reported & $\begin{array}{l}\text { Select one: } \\
1=\text { yes } \\
0=\text { no }\end{array}$ & $\begin{array}{l}\text { - Yes = the meta-analysis provided the total number of } \\
\text { students } \\
\text { - No = the meta-analysis did not provide any information } \\
\text { on the total number of students }\end{array}$ \\
\hline AS & $\begin{array}{l}\text { Grade Range } \\
\text { Reported }\end{array}$ & $\begin{array}{l}\text { Select one: } \\
1=\text { yes } \\
0=\text { no }\end{array}$ & $\begin{array}{l}\text { - Yes }=\text { the meta-analysis provided some information on } \\
\text { grade or age of participants } \\
\text { - No = the meta-analysis did not provide any information } \\
\text { on age or grade of participants }\end{array}$ \\
\hline AT & Gender Reported & $\begin{array}{l}\text { Select one: } \\
1=\text { yes } \\
0=\text { no }\end{array}$ & $\begin{array}{l}\text { - Yes = the meta-analysis provided some information on } \\
\text { gender of children } \\
\text { No = the meta-analysis did not provide any information } \\
\text { on gender of children }\end{array}$ \\
\hline AU & Race Reported & $\begin{array}{l}\text { Select one: } \\
1=\text { yes } \\
0=\text { no }\end{array}$ & $\begin{array}{l}\text { - Yes = the meta-analysis provided some information on } \\
\text { race/ethnicity of children } \\
\text { - No = the meta-analysis did not provide any information } \\
\text { on race/ethnicity of children }\end{array}$ \\
\hline AV & ELL/ESL Reported & $\begin{array}{l}\text { Select one: } \\
1=\text { yes } \\
0=\text { no }\end{array}$ & $\begin{array}{l}\text { - Yes = the meta-analysis provided some information on } \\
\text { ELL status of children } \\
\text { - No = the meta-analysis did not provide any information } \\
\text { on ELL status of children }\end{array}$ \\
\hline AW & $\begin{array}{l}\text { SES or FRL } \\
\text { Reported }\end{array}$ & $\begin{array}{l}\text { Select one: } \\
1=\text { yes } \\
0=\text { no }\end{array}$ & $\begin{array}{l}\text { - Yes = the meta-analysis provided some information on } \\
\text { SES or FRL status of children } \\
\text { - No = the meta-analysis did not provide any information } \\
\text { on SES or FRL status of children }\end{array}$ \\
\hline
\end{tabular}


Quality of Data Analysis Plan and Methodological Information

\begin{tabular}{|c|c|c|c|}
\hline Cell & Variable & Description & Explanation \\
\hline $\mathrm{AX}$ & $\begin{array}{l}\text { Quality of } \\
\text { Procedures for Data } \\
\text { Analysis Plan }\end{array}$ & $\begin{array}{l}\text { Select one: } \\
0=\text { no } \\
1=\text { yes }\end{array}$ & $\begin{array}{l}\text { The method for aggregating the results (e.g., aggregating effect } \\
\text { sizes) in order to describe patterns within the literature was } \\
\text { described. }\end{array}$ \\
\hline AY & Type of Effect Size & $\begin{array}{l}\text { Select all that apply: } \\
0=\text { Not Reported } \\
1=\text { Cohen's d ES } \\
2=\text { Hedges g ES } \\
3=\text { Eta-squared ES } \\
4=\text { Tau U } \\
5=\text { PND (percent of non- } \\
\text { overlapping data) } \\
6=\text { PAND (percentage of all } \\
\text { non-overlapping data) } \\
7=\text { SMD (standard mean } \\
\text { difference) } \\
8=\text { IRD (Improvement Rate } \\
\text { Difference) } \\
9=\text { LLR = log response ratio } \\
10=\text { Phi } \\
11=\text { PEM (percentage of data } \\
\text { points exceeding the median) } \\
12=\text { Other } \\
\text { Separate responses using a } \\
\text { semi-colon (e.g., " } 1 ; 3 ; 4 \text {;) }\end{array}$ & $\begin{array}{l}\text { What type of effect size(s) researchers reported in the meta- } \\
\text { analysis, for example, hedges'g } \\
\text { Note: codes } 1-3 \text { are common for group design studies; codes } 4- \\
11 \text { are common for SCD. }\end{array}$ \\
\hline $\mathrm{AZ}$ & $\begin{array}{l}\text { Type of Meta } \\
\text { Analytic Method }\end{array}$ & $\begin{array}{l}\text { Select all that apply: } \\
0=\text { Not Reported } \\
1=\text { fixed effect meta-analysis } \\
2=\text { random effect meta-analysis } \\
3=\text { meta regression analysis } \\
4=\text { moderator analysis } \\
5=\text { mixed effect analysis }\end{array}$ & $\begin{array}{l}\text { Note. This code refers to whether researchers provide } \\
\text { description of analytic methods. In other words, the code } \\
\text { refers to which type of meta-analysis analytic method } \\
\text { researchers used in the meta-analysis. } \\
\text { In order to identify analytic models, look into the meta- } \\
\text { analytic model section. For example, }\end{array}$ \\
\hline
\end{tabular}




\begin{tabular}{|c|c|c|c|}
\hline & & $\begin{array}{l}6=\text { sensitivity analysis } \\
7=\text { meta-analysis of single-case } \\
\text { design } \\
8=\text { other } \\
\text { Separate responses using a } \\
\text { semi-colon (e.g., " } 1 ; 3 ; 4 \text { ") }\end{array}$ & $\begin{array}{l}\text { "We used a random-effects meta-regression model" will be } \\
\text { coded as } 2 \text { and } 3 \text {, or "Additional moderator analysis was } \\
\text { conducted" will be coded as } 4 \text {. } \\
\text { Another way to identify analytic models is look into the title of } \\
\text { tables. For example, "Table } 2 \text {. Parameter Estimates From RVE } \\
\text { Random-Effects Model and Meta-Regression Correction } \\
\text { Methods" will be coded as } 2 \text { and } 3 \text {. }\end{array}$ \\
\hline BA & $\begin{array}{l}\text { Type of Meta- } \\
\text { analysis software }\end{array}$ & $\begin{array}{l}\text { Select one code: } \\
0=\text { Not Reported } \\
1=\text { R software } \\
2=\text { Comprehensive Meta- } \\
\text { Analysis Software (CMA) } \\
3=\text { Review Manager (RevMan) } \\
4=\text { Stata } \\
5=\text { SAS } \\
6=\text { JASP } \\
7=\text { Jamovi } \\
8=\text { Meta-Essentials } \\
9=\text { MetaXL } \\
10=\text { MetaEasy } \\
11=\text { Other }\end{array}$ & $\begin{array}{l}\text { Note. This code refers to whether researchers provide } \\
\text { descriptions of analysis software. } \\
\text { To identify software, look into the description of meta-analysis } \\
\text { or at the end of the method section. Another way to identify } \\
\text { software is to search "software" in search terms in the article. } \\
\text { For example, "We calculated ESs } \\
\text { using R software (version 3.3.0; R Core Team, 2016) for each } \\
\text { treatment and comparison contrast on all mathematics- related } \\
\text { outcomes" will be coded as 1, and "We used the } \\
\text { Comprehensive Meta-Analysis software (Borenstein, } \\
\text { Hedges, Higgins, \& Rothstein, 2006) for data analysis" will be } \\
\text { coded as } 2 \text {. }\end{array}$ \\
\hline
\end{tabular}

\section{Quality of the Results}

\begin{tabular}{|l|l|l|l|}
\hline Cell & Variable & Code & Explanation \\
\hline BB & Publication Bias & $\begin{array}{l}\text { Select one: } \\
0=\text { no } \\
1=\text { yes }\end{array}$ & $\begin{array}{l}\text { This code refers to whether or not authors provided results for } \\
\text { publication bias analysis such as the Classic Fail } N \text { test, a funnel } \\
\text { plot, etc. This may be reported in the Method, or in a } \\
\text { Supplementary Figure. }\end{array}$ \\
\hline
\end{tabular}




\begin{tabular}{|l|l|l|l|}
\hline BC & Long-term Effectiveness & $\begin{array}{l}\text { Select one: } \\
0=\text { no } \\
1=\text { yes, summary effect } \\
\text { (or other analysis) for } \\
\text { delayed post-test }\end{array}$ & $\begin{array}{l}\text { This code refers to whether or not authors evaluated summary } \\
\text { effects beyond post-test, such as with a delayed post-test analysis. }\end{array}$ \\
\hline $\begin{array}{l}\text { BD - } \\
\text { BF }\end{array}$ & $\begin{array}{l}\text { Interpretation of the } \\
\text { Results }\end{array}$ & $\begin{array}{l}\text { Select all that apply: } \\
\text { angeneralizability of the } \\
\text { results is discussed } \\
1=\text { limitations } \\
2=\text { recommendations or } \\
\text { implications } \\
\text { Separate codes with a } ;\end{array}$ & $\begin{array}{l}\text { Codes Defined: } \\
0=\text { authors described the generalizability of the conclusions of the } \\
\text { results of the meta-analysis including the relevant student and } \\
\text { teacher populations as well as the appropriate contexts and } \\
\text { variables of the results. This may also be achieved with authors } \\
\text { discussing how their results apply to specific populations or do } \\
\text { not generalize; perhaps also by making connections with previous } \\
\text { research. } \\
1=\text { authors directly acknowledged limitations of the current study } \\
2=\text { authors recommended next steps or provided implications of } \\
\text { the review for relevant domains such as research, practice, policy, } \\
\text { and theory as applicable. }\end{array}$ \\
\hline
\end{tabular}

